\title{
Descriptive Anatomy of Lateral Digital Extensor Muscles of the Hand of the White-Footed Tamarin (Saguinus leucopus Günther, 1876).
}

\author{
Anatomía Descriptiva de los Músculos Extensores Digitales Laterales \\ de la Mano del Tití Gris (Saguinus leucopus Günther, 1876).
}

\author{
Juan Fernando Vélez García*; Jorge Eduardo Duque Parra****** \& John Barco Ríos**
}

VÉLEZ, G. J. F.; DUQUE, P. J. E. \& BARCO, R. J. Descriptive anatomy of lateral digital extensor muscles of the hand of the whitefooted tamarin (Saguinus leucopus günther, 1876). Int. J. Morphol., 34(3):1123-1127, 2016.

SUMMARY: The Saguinus leucopus is an endemic and monotypic primate of Colombia with quadrupedal arboreal locomotion, but the study of its morphological adaptations are still scarce, therefore the specific knowledge of its muscles will allow to understand these adaptations and to establish better medical and surgical procedures in order to preserve this species. For this purposes, the two forearms of $10 \mathrm{~S}$. leucopus specimens were dissected, they were fixed within a formaldehyde solution, phenic acid and mineral oil mixture. Among the craniolateral muscles of the forearm two muscles were independent for digits IV and V. They presented form, origin and insertion suitable for individual extension of each digit, with innervation and irrigation by the cranial interosseous nerve and the homonymous artery respectively; they show similarities and differences with other primates, it allows to conclude that the development of these muscles could enable a particular anatomical and functional individualization in these digits extension, this feature makes possible its quadrupedal arboreal locomotion. Primate.

KEY WORDS: Antebrachial region; Extensor digiti quarti proprius muscle; Extensor digiti quinti proprius muscle; Myology;

\section{INTRODUCTION}

White-footed tamarin (Saguinus leucopus) is a neotropical endemic and monotypic primate of Colombia (Defler, 2010) categorized by the IUCN (International Union for Conservation of Nature and Natural Resources) as an endangered species due to a significant reduction in the population, mainly due to illegal animal trade as pets (Morales-Jiménez et al., 2008). This situation makes them susceptible to arrive at the Wildlife Care and Assessment Center and zoos to be assessed by veterinarians, moreover, this species anatomical knowledge is scarce (Stevenson et al., 2010), which hinders their medical and surgical care. In a study conducted by URRAS (Unidad de Rescate y Rehabilitación de Animales Silvestres), the clinical examination revealed that a third of the greatest abnormalities were in musculoskeletal system (Varela et al., 2010). Therefore, knowing the muscle morphology is important to know its muscular adaptation for locomotion (Kardong, 2012), and establish better medical and surgical procedures. These primates have quadrupedal locomotion moving over trunks and branches of trees (Defler).
Therefore, they must work properly for the movement. The extensor digitorum lateralis muscle is among the craniolateral muscles of the forearm of domestic mammals. It serves to support the extensor digitorum communis muscle for the hand lateral digits, as it happens in the domestic dog for the three lateral digits (Budras et al., 2007; Evans \& De Lahunta, 2013), and in the domestic cat (König \& Liebich, 2011), although in this the four lateral digits are reported (Barone, 2000). Furthermore, in humans posterior compartment of the forearm the extensor digiti minimi is reported due to the common pattern that only goes to this digit (Testut \& Latarjet, 1984; Federative International Committee on Anatomical Terminology, 1998; Standring, 2008 ), but in other primates it is reported to the digit IV (Champneys, 1871; Hepburn, 1892; Primrose, 1900; Osman Hill, 1959; Kimura \& Takai, 1970; Aziz \& Dunlap, 1986; Ackermann, 2003; Cribillero et al., 2009; Aversi-Ferreira et al., 2010; Diogo \& Wood, 2012), and it is even described as absent in Galagos (Stevens et al., 1977; Ackermann).

\footnotetext{
* Departamento de Sanidad Animal, Facultad de Medicina Veterinaria y Zootecnia, Universidad del Tolima, Ibagué, Colombia.

** Departamento de Ciencias Básicas, Universidad de Caldas en convenio con CORPOCALDAS, Manizales, Colombia.

**** Departamento de Ciencias Básicas Biológicas, Universidad Autónoma de Manizales, Manizales, Colombia.
} 


\section{MATERIAL AND METHOD}

Both S. leucopus forearms from five females and five males were dissected in an epicritic form. They were ethically obtained; they died by natural causes in Wildlife care and assessment centers of CORPOCALDAS (Colombia), and they weighed between 300 and $460 \mathrm{~g}$. They were fixed with subcutaneous, intramuscular, and in cavities infiltrations with a solution of $10 \%$ formalin, $5 \%$ mineral oil, and $1 \%$ phenic acid. They were immersed in plastic buckets the same mixture but without mineral oil solution. The terminology for quadruped animals present in the Nomina Anatomica Veterinaria for description (International Committee on Veterinary Gross Anatomical Nomenclature, 2012) was used, and photographic records were taken.

\section{RESULTS}

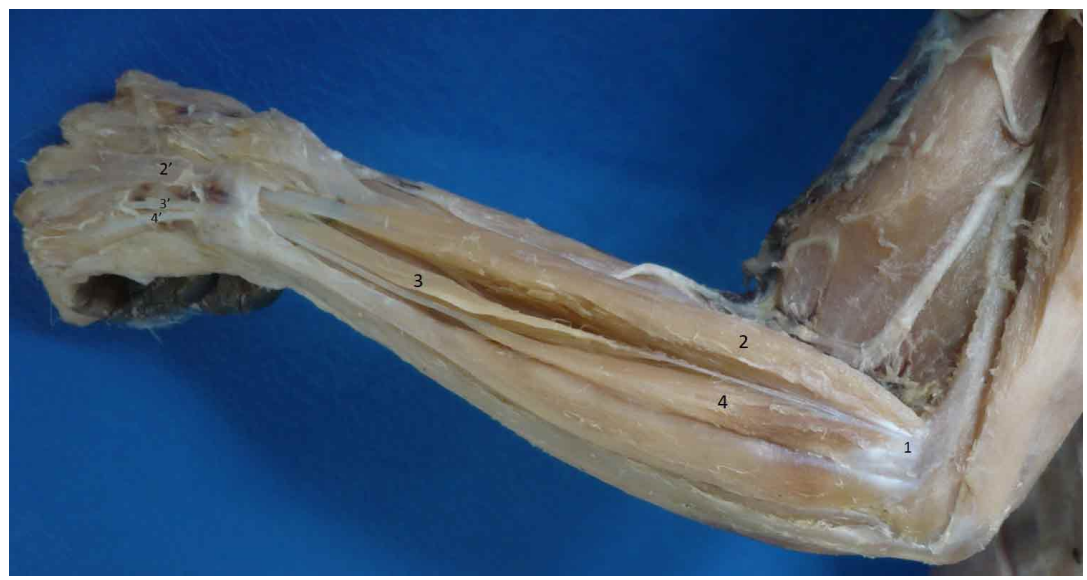

Fig.1. Superficial digital extensor muscles of the left forearm. The Superficial digital extensor muscles have been separated from interseptal origins to display separation. Common tendon originate in the most distal part of the lateral supracondylar crest and lateral epicondyle of the humerus (1). Extensor digitorum communis (2), extensor digiti IV proprius (3), extensor digiti V proprius (4); and respective tendons (2', 3', 4').

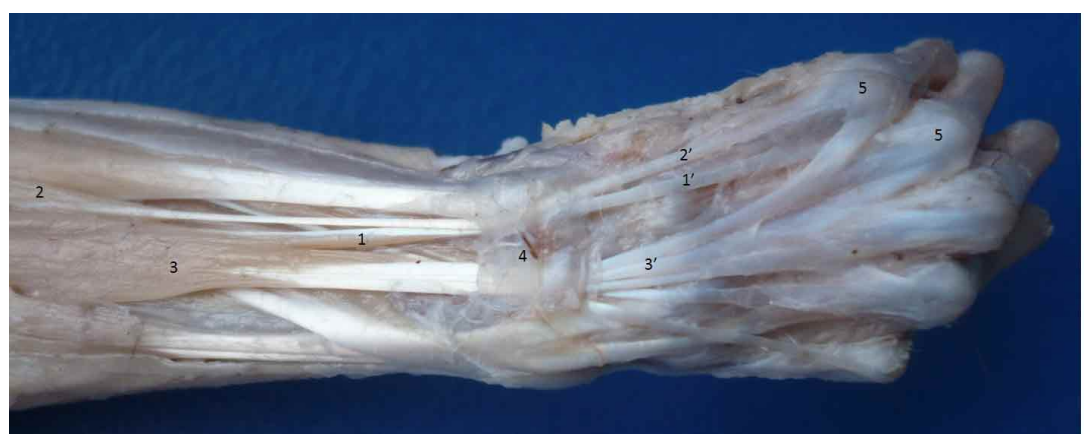

Fig. 2. Cranial view of the left forearm and hand of a S. leucopus. Extensor digiti IV proprius (1), Extensor digiti $\mathrm{V}$ proprius (2), Extensor digitorum communis (3), its tendons (1', 2', 3'), Retinaculum extensor (4), Dorsal extensor expansion (5).
In the ten $S$. leucopus specimens two independent lateral digital extensor muscles were found, they were between the craniolateral antebrachial muscles These extensors are called the extensor digiti IV proprius muscle (extensor digiti quarti proprius) and extensor digiti $\mathrm{V}$ proprius muscle (extensor digiti quinti proprius), they are between the extensor digitorum communis muscle and extensor carpi ulnaris muscle.

The extensor digiti IV proprius is a unipennate and elongated muscle that is at the middle third of the intermuscular septum that limits with the extensor digitorum communis. This fibrous septum projects towards the proximal that forms a common tendon from the lateral epicondyle of the humerus with the extensor digitorum communis and the extensor digiti $\mathrm{V}$ proprius muscle (Fig. 1). The muscular belly of extensor digiti IV proprius goes from the middle of the forearm to the proximal part of the carpal where its tendon passes along with the tendon of the extensor digiti $\mathrm{V}$ proprius through the more lateral compartment that forms the extensor retinaculum, and enters into the abaxial part of the dorsal extensor expansion that form at the level of the metacarpophalangeal joint of the digit IV (Fig. 2).

The extensor digiti $\mathrm{V}$ proprius is a fusiform and elongated muscle that arises in the lateral epicondyle of the humerus by a common tendon with the extensor digitorum communis and extensor digiti IV proprius. It also arises in the proximal third of the intermuscular septum that separates it from the extensor digitorum communis, and from the antebrachial fascia that covers it. Its muscular belly is in the two proximal thirds of the forearm, and develops a tendon to distal that inserts into the abaxial part of the dorsal extensor expansion of the digit V (Fig. 2).

These two muscles are innervated by independent muscular branches of the interosseous cranial nerve, which is the extension of deep branch of radial nerve when passes the supinator muscle. They are also irrigated independently by branches of the cranial interosseous artery (Fig. 3). 


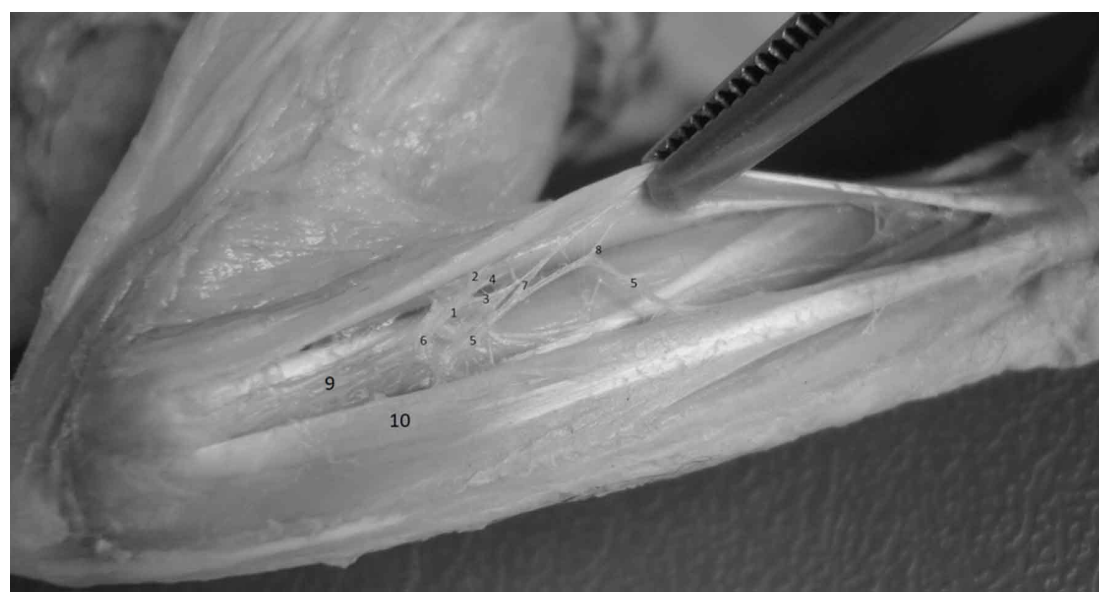

Fig. 3. Lateral view of the right forearm of a specimen. The superficial extensor muscles of the digits have been retracted to display its innervation through cranial interosseous nerve (1) with its branches to the extensor digiti $\mathrm{V}$ proprius (2), extensor digiti IV proprius (3), and extensor digitorum communis (4); as irrigation by interosseous cranial artery (5) and its muscle branches for the extensor digiti V proprius (6), extensor digiti IV proprius (7) and extensor digitorum communis (8). Supinator (9) and extensor carpi ulnaris muscles (10).

\section{DISCUSSION}

The presence of a separate muscle for the digit IV and one for the digit $\mathrm{V}$ has been reported in other species different from S. leucopus, such as in Ateles geoffroyi, in wich the extensor digiti IV proprius arises deeply in the common digital extensor muscle. The extensor digiti $\mathrm{V}$ proprius described in Cercopithecus aethiops and Cercopithecus talapoin is divided into two muscles that supply the digits IV and V (Aziz \& Dunlap). Two independent muscles have also been found in Papio hamadryas, where the extensor digiti IV proprius arises from the lateral epicondyle of the humerus and inserts on the dorsal aspect of the proximal phalanx (Ackermann), but it has also been found that in this species only one muscle leads to the digits IV and V (Champneys; Hepburn). In Macaca mulatta and Macaca fascicularis named independenly, the descriptions report as a single muscular belly, in which the tendon is divided to digits IV and V (Ackermann; Kimura $\&$ Takai). This is an anatomical feature that occurs in Macaca nemestrina (Aziz \& Dunlap), Cebus libidinosus (AversiFerreira et al.), Cebus albifrons (Cribillero et al.), Callimico goeldii (Osman Hill), Pongo pygmaeus (Aziz \& Dunlap; Diogo \& Wood; Primrose), and Macaca fascicularis (Kimura \& Takai). This division is also rarely present in humans (Standring; Testut \& Latarjet) and other primates except $P a n$ troglodytes, Gorilla gorilla (Aziz \& Dunlap; Diogo \& Wood; Hepburn), gibbons (Aziz \& Dunlap; Diogo \& Wood; Hepburn; Michilsens et al., 2009), Saguinus geoffroyi (Aziz
\& Dunlap), and Saguinus oedipus (Ackermann). In these, extensor digiti $\mathrm{V}$ proprius has only been found for the digit $\mathrm{V}$, as happens with the common human pattern (Standring; Testut \& Latarjet), it presents similarities to $S$. leucopus, although they do not have an individual muscle for the digit IV. An independent muscle has been found in Nycticebus pygmaeus for the digit $\mathrm{V}$, but it has also been found corresponding to the digits IV and V (Diogo \& Wood). The muscle is described as absent in Galago senegalensis (Stevens et al.) and Galago crassicaudatus (Ackermann), but its functional equivalent has been found in the extensor digitorum communis, similar to what happens in Hylobates lar, in which it has been fused to it (Michilsens et al.). These variations can occur in humans (Standring), but are not found in S. leucopus.

Regarding the origin of the S. leucopus extensor digiti V proprius, it differs from humans (Testut \& Latarjet; Standring) because it arises from the intermuscular septum with flexor carpi ulnaris and differs from $C$. libidinosus (Aversi-Ferreira et al.), P. pygmaeus (Aziz \& Dunlap) H. lar and H. gabriellae (Diogo \& Wood) because it origin is reported from the antebrachial fascia. No origins were found in the ulna of the S. leucopus, which is a variant that has been reported in humans (Testut \& Latarjet). In Ateles sp there is a description of an ulnar origin near the carpus (Ackermann); in Symphalangus syndactylus and H. lar its origin has been reported towards the middle of the ulna, and in Pongo pygmaeus in the proximal part of the ulna (Diogo \& Wood). The S. leucopus innervation and irrigation of this muscle is similar to the one reported in humans (Testut \& Latarjet; Standring) and differs from the irrigation in $C$. libidinosus as it is directly described in the radial artery (Aversi-Ferreira et al.).

In conclusion, the development of a single muscle to the digit IV and another for the digit V of the S. leucopus, suggests that this species has a particular anatomical and functional individualization in the extension of these digits, a feature, that enables them to use these digits to climb down off the branches and trunks of trees. This suggests that this condition is essential for the quadrupedal arboreal locomotion in a palmigrade way, as it demands longer an extension of the digits. This finding and anatomical description also suggests more anatomic studies to understand its role in the locomotor behavior of this animal. 
VÉLEZ, G. J. F.; DUQUE, P. J. E. \& BARCO, R. J. Anatomía descriptiva de los músculos extensores digitales laterales de la mano del Tití Gris (Saguinus leucopus günther, 1876). Int. J. Morphol., 34(3):1123-1127, 2016.

RESUMEN: El Saguinus leucopus es un primate endémico y monotípico de Colombia con la locomoción cuadrúpeda arbórea, sin embargo los estudios de sus adaptaciones morfológicas aún son escasos, por lo tanto, el conocimiento específico de sus músculos permitirá conocer estas adaptaciones y establecer mejores procedimientos médicos y quirúrgicos con el fin de preservar esta especie. Para estos fines, se disecaron los dos antebrazos de 10 especímenes de S. leucopus, los cuales fueron fijados con una solución en mezcla de formaldehído, aceite mineral y ácido fénico. Entre los músculos cráneo laterales del antebrazo se encontraron dos músculos independientes para los dígitos IV y V. La forma, el origen y la inserción eran adecuadas para la extensión individual de cada dígito, con la inervación e irrigación por el nervio interóseo craneal y la arteria del mismo nombre respectivamente, presentando similitudes y diferencias con otros primates, lo que permite llegar a la conclusión que el desarrollo de estos músculos podría permitir una individualización anatómica y funcional particular en la extensión de estos dígitos, haciendo posible su locomoción cuadrúpeda arbórea.

PALABRAS CLAVE: Región antebraquial; Músculo propio del extensor del dedo Quarti; Músculo Extensor del dedo quinti proprius; Miología; Primate.

\section{REFERENCES}

Ackermann, R. R. A Comparative Primate Anatomy. Dissection Manual. Cape Town, University of Cape Town, 2003.

Aziz, M. A. \& Dunlap, S. S. The human extensor digitorum profundus muscle with comments on the evolution of the primate hand. Primates, 27(3):293-319, 1986.

Aversi-Ferreira, T. A.; Diogo, R.; Potau, J. M.; Bello, G.; Pastor, J. F. \& Aziz, M. A. Comparative anatomical study of the forearm extensor muscles of Cebus libidinosus (Rylands et al., 2000; Primates, Cebidae), modern humans, and other primates, with comments on primate evolution, phylogeny, and manipulatory behavior. Anat. Rec. (Hoboken), 293(12):2056-70, 2010.

Barone, R. Anatomie Comprée des Mammifères Domestiques. Tome 2, Arthrologie et Myologie. $4^{\text {th }}$ ed. Paris, Vigot, 2000.

Budras, K. D.; McCarthy P. H.; Fricke, W. \& Richter, R. Anatomy of the Dog. $5^{\text {th }}$ ed. Hannover, Schlütersche, 2007.

Champneys, F. The muscles and nerves of a chimpanzee (Troglodytes niger) and a cynocephalus anubis. J. Anat. Physiol., 6(Pt. 1):176-211,1871.

Cribillero, Ch. N.; Sato, S. A. \& Navarrete, Z. M. Anatomía macroscópica de la musculatura del miembro anterior del mono machín blanco (Cebus albifrons). Rev. Investig. Vet. Perú, 20(2):143-53, 2009.

Defler, T. R. Historia Natural de los Primates Colombianos. $2^{\mathrm{a}} \mathrm{ed}$. Bogotá, Universidad Nacional de Colombia, 2010.

Diogo, R. \& Wood, B. Comparative Anatomy and Phylogeny of Primate Muscles and Human Evolution. Boca Raton, CRC Press, 2012.

Evans, H. E. \& De Lahunta, A. Millers Anatomy of the Dog. $4^{\text {th }}$ ed. London, Elsevier Health Sciences, 2013.
Federative International Committee on Anatomical Terminology (FICAT). Terminologia Anatomica. International Anatomical Terminology. New York, Thieme Medical Publishers, 1998.

Hepburn, D. The Comparative Anatomy of the Muscles and Nerves of the Superior and Inferior Extremities of the Anthropoid Apes: Part I. J. Anat. Physiol., 26(Pt. 2):149-86, 1892.

Osman Hill, W.C. The anatomy of Callimico goeldii (Thomas): A primitive american primate. Trans. Am. Philos. Soc., 49(5):1-116, 1959.

International Committee on Veterinary Gross Anatomical Nomenclature (ICVGAN). Nomina Anatomica Veterinaria. $5^{\text {th }}$ ed. Hannover, World Association of Veterinary Anatomists, 2012.

Kardong, K. V. Vertebrates: Comparative Anatomy, Function, Evolution. ${ }^{\text {th }}$ ed. New York, Mc Graw Hill, 2012.

Kimura, K. \& Takai, S. On the musculature of the forelimb of the crab-eating monkey. Primates, 11(2):145-70, 1970.

König, H. E. \& Liebich, H. G. Anatomía de los Animales Domésticos. Tomo I. Aparato Locomotor. $2^{\text {nd }}$ ed. Buenos Aires, Editorial Médica Panamericana, 2011.

Morales-Jiménez, A. L.; Link, A. \& Stevenson, P. Saguinus leucopus. The IUCN Red List of Threatened Species, 2008: T19819A9019454, 2008. Available from: http://dx.doi.org/ 10.2305/IUCN.UK.2008.RLTS.T19819A9019454.en

Michilsens, F.; Vereecke, E. E.; D'août, K. \& Aerts. P. Functional anatomy of the gibbon forelimb: adaptations to a brachiating lifestyle. J. Anat., 215(3):335-54, 2009.

Primrose, A. The Anatomy of the Orang Outang. Toronto, University Library, 1900. Available from: http:// www.archive.org/details/cihm_14732 
VÉLEZ, G. J. F.; DUQUE, P. J. E. \& BARCO, R. J. Descriptive anatomy of lateral digital extensor muscles of the hand of the white-footed tamarin (Saguinus leucopus günther, 1876). Int. J. Morphol., 34(3):1123-1127, 2016.

Standring, S. Gray's Anatomy: The Anatomical Basis of Clinical Practice. $14^{\text {th }}$ ed. Edinburgh, Churchill Livingstone, 2008.

Stevens, J. L.; Meyer, D. M. \& Edgerton, V. R. Gross anatomy of the forelimb and shoulder girdle of the Galago senegalensis. Primates, 18(2):435-52, 1977.

Stevenson, P. R.; Guzmán, D. C. \& Defler, T.R. Conservation of Colombian primates: An analysis of published research. Trop. Conserv. Sci., 3(1):45-62, 2010.

Testut, L. \& Latarjet, A. Tratado de Anatomía Humana. $9^{a}$ ed. Barcelona, Salvat Editores, 1984.

Varela, N.; Brieva, C. \& Galindo, C. Causas de mortalidad y morbilidad en primates de la unidad de rescate y rehabilitación de animales silvestres (URRAS) entre 1996 y 2003. En: Pereira-Bengoa V.; Stevenson, P. R.; Bueno, M. L. \& NassarMontoya, F. Primatología en Colombia. Avances al Principio del Milenio. Bogotá, Fundación Universitaria San Martín, 2010. pp.171-89.
Correspondence to:

Juan Fernando Vélez García

Departamento de Sanidad Animal

Facultad de Medicina Veterinaria y Zootecnia

Universidad del Tolima

Ibagué

COLOMBIA

Email: jfvelezg@ut.edu.co

Received: 28-11-2015

Accepted: 12-07-2016 